International Journal of Biology, Pharmacy and Allied Sciences (IJBPAS) 'A B Bridge Betuen Caboratory and QRando'

Www.iibpas.com

\title{
EFFECT OF DIFFERENT DIETARY PROTEIN LEVELS ON PROXIMATE COMPOSITION OF LABEO CALBASU FROM PAKISTAN
}

\section{BANO S, NAEEM M* AND MASUD S}

Institute of Pure and Applied Biology, Bahauddin Zakariya University, Multan, Pakistan

*Corresponding Author's: E Mail: muhammadnaeem@bzu.edu.pk; +923337378881

Received 19 ${ }^{\text {th }}$ March 2019; Revised $18^{\text {th }}$ April 2019; Accepted 19 ${ }^{\text {th }}$ May 2019; Available online $1^{\text {st }}$ Nov. 2019 https://doi.org/10.31032/IJBPAS/2019/8.11.4855

\begin{abstract}
Proximate body composition analysis implies percent composition of moisture, lipids and protein. The aim of the study of to evaluate the effect of the various levels of dietary protein on the body composition of Labeo calbasu. Fish were fed with $15 \%, 20 \%$ and $25 \%$ crude protein in diet in treatment 1 (T1), treatment 2 (T2) and treatment 3 (T3), respectively. At the end of feeding trial, a total of 120 samples of Labeo calbasu, 40 belonging to each of the three dietary protein treatments were evaluated for proximate body composition. Mean water, ash, fat and protein in wet weigh of $L$. calbasu were ranged 76.59-77.19\%, 3.63-4.68\%, 4.08$4.86 \%$ and $13.87-15.66 \%$, respectively, in different treatments. Ash and fat percentages were found highest in T1, water parentage was found highest in T2, while mean protein content percentage value was found highest in T3 (25\% crude protein). All the body constituents were found to be highly correlated $(\mathrm{P}<0.001)$ with the fish size (length and weight) in $\mathrm{T} 1, \mathrm{~T} 2$ and $\mathrm{T} 3$, except for ash contents in $\mathrm{T} 2(\mathrm{r}=0.472)$ and $\mathrm{T} 3(\mathrm{r}=0.412)$ showing correlation at $\mathrm{P}<0.01$. Slope ( $\mathrm{b}$ value) indicated positive correlations in all the relationships between fish size and different constituents. No studies on L. calbasu have yet attempted to evaluate the effect of dietary protein levels on body composition and to relate the size of the fish with the parameters of whole body composition. Thus, this study will provide the first reference from Pakistan.
\end{abstract}

Key words: Carp, Labeo calbasu, dietary protein, Fat, Ash, Protein contents, Regression analysis, Fish size

\section{INTRODUCTION}

Fish culturing has been increased to solve industry in aquaculture not only provide problem of food shortage. Fisheries food resources but also increased chances 
of livelihood and income for increasing population [1].

Water, protein, ash and lipids are the significant segments of palatable portion of fish. Proximate body composition implies the examination of protein, water, fat and ash remains of fish. The protein is the best source in fish [2].

In live fish, water is the major constituent while protein makes second important constituent of fish body. Lower percentage of water in fish may result higher level of the protein and fats and thus more noteworthy the vitality estimation of the fish [3].

The data of body composition of fish is critical for nutritionists who are keen on low fat and high protein sustenance. This data is additionally vital for researchers who are chipping away at forming these nourishments into astounding sustenance which may have high protein. This also guarantees the fine meat quality and flavour [4]. However, proximate composition may vary with size $[5,6]$, season [7] and dietary protein levels [8].

Labeo calbasu is an herbivorous fish and commercially important species often cultured in Pakistan, South Western China, Bangladesh, Thailand and India $[1,9]$.

The present work was aimed to study the effect of different dietary protein levels $(15 \%, 20 \%$ and $25 \%)$ on the proximate composition and its relation to body size of an economically important fish species, Labeo calbasu, from Pakistan.

\section{MATERIALS AND METHODS}

Total 120 specimens of Labeo calbasu were taken for analysis of body composition, 40 samples from each of the three treatments i.e., $\mathrm{T} 1, \mathrm{~T} 2$ and $\mathrm{T} 3$ in which fish were fed with $15 \%, 20 \%$ and $25 \%$ dietary protein levels, respectively. The live fish were anesthetized by MS222. Weight and total length (TL) of fish was noted.

Fish samples were dried in electric oven at $70^{\circ} \mathrm{C}$ till constant weight. Dried samples were weighted to calculate the water contents in the fish. The dry samples were then grinded to make powder. The dry powder sample of each fish was kept in plastic bottles with proper labelling, for further analyses.

For ash analyses in fish samples, $1 \mathrm{~g}$ powder sample was taken in preweighed heat resistant crucibles, which were subjected to $500^{\circ} \mathrm{C}$ in muffle furnace for $24 \mathrm{hr}$, after which these were reweighted to calculate the ash contents in L. calbasu.

To calculate lipids, methodology of Bligh and Dyer [10] was applied, by using a mixture of chloroform and methanol in a $1: 2$ ratio. For this purpose, $1 \mathrm{~g}$ sample powder of L. calbasu was taken in test tube and $10 \mathrm{ml}$ solution was added in it. It was remained undisturbed for whole night and then subjected to centrifugation. 
Supernatant was shifted in preweighed glass bottles and kept in oven till dryness and constant weight. Glass bottles were reweighted to determine the lipid contents.

Protein contents in L. calbasu samples were assessed by subtracting the weight of other major contents (ash, water, fat) from total weight of fish, following $[5,6]$.

Statistical analysis including regression evaluations were carried out by using computer programmes, MS-Excel and MiniTab.

\section{RESULTS}

A total of 120 samples of Labeo calbasu, 40 belonging to each of the three treatments $\mathrm{T} 1, \mathrm{~T} 2$ and $\mathrm{T} 3$ (T1 with $15 \%$ dietary protein level, T2 with $20 \%$ dietary protein level and T3 with $25 \%$ dietary protein level), were evaluated for proximate body composition. Total length was measured to $11.89 \pm 1.79 \mathrm{~cm}$, weight was found $22.59 \pm 9.98 \mathrm{~g}$, while condition factor was recorded as $1.27 \pm 0.17$.

Water content in Labeo calbasu were found highest in treatment 2 (T2), in which fish were fed with $20 \%$ dietary protein, followed by treatment 1 (T1, 15\% dietary protein) and treatment 3 (T3, 25\% dietary protein). The highest mean values of ash and fat contents were found in $\mathrm{T} 1$, while these were the lowest in $\mathrm{T} 3$, for both wet and dry body weight of L. calbasu. The results shows that ash and fat content values decrease with an increase in dietary protein level from $15 \%$ to $25 \%$. Mean value of protein content was found the highest in T3, followed by T2 and T1, for wet and dry body weight of $L$. calbasu, indicating the increase in protein contents by feeding the fish with higher dietary protein level (Table $1)$.

Ash and fat percentages were found highest in $\mathrm{T} 1$, water parentage was found highest in $\mathrm{T} 2$, while mean protein content percentage value was found highest in T3 $(25 \%$ crude protein) (Table 2).

All the body constituents were found to be highly correlated $(\mathrm{P}<0.001 ; \mathrm{r}=0.643$ to 0.998 ) with weight of $L$. calbasu in T1, T2 and $\mathrm{T} 3$, except for ash contents in $\mathrm{T} 2 \mathrm{(r}=$ $0.472)$ and $\mathrm{T} 3 \quad(\mathrm{r}=0.412)$ showing correlation at $\mathrm{P}<0.01$. Slope (b value) indicated positive correlations. B-value also indicated isometry (b being close to 1.00 ) for water contents in $\mathrm{T} 1$ and fat in $\mathrm{T} 2$ with weight of L. calbasu. Results showed positive allometry $(b>3)$ in the relationships between protein contents and body weight of L. calbasu, from all the treatments. However, ash content in all treatments, water in $\mathrm{T} 2$ and $\mathrm{T} 3$, and fat in $\mathrm{T} 1$ and $\mathrm{T} 3$ showed negative allometry with increase in the fish body weight (Table 3).

TL of L. calbasu represented significant positive correlation. Protein content in T2 and T3 represented positive allometry (b $>3$ ), while water and ash contents showed negative allometry with TL (Table 4). 
Results of Table 5 showed that all the body constituents remained constant with condition factor in all treatments, except for water in $\mathrm{T} 2$, and fat and ash in $\mathrm{T} 1$, which showed significant $(\mathrm{P}<0.05)$ relationships with the condition factor in L. calbasu.

Table 1: Percent constituents of $L$. calbasu from different treatments

\begin{tabular}{|c|c|c|c|c|c|c|}
\hline Body constituents & \multicolumn{2}{|c|}{$T 1$} & \multicolumn{2}{|c|}{$T 2$} & \multicolumn{2}{|c|}{$T 3$} \\
\hline & $\begin{array}{l}\text { Mean } \\
\pm \text { S.D }\end{array}$ & Range & $\begin{array}{l}\text { Mean } \\
\pm \text { S.D }\end{array}$ & Range & $\begin{array}{l}\text { Mean } \\
\pm \text { S.D }\end{array}$ & Range \\
\hline Water content (\%) & $76.59 \pm 2.77$ & 68.59-81.21 & $77.19 \pm 2.40$ & 72.73-82.03 & $76.64 \pm 2.64$ & 72.36-83.16 \\
\hline $\begin{array}{c}\text { Ash content (\%Wet } \\
\text { weight) }\end{array}$ & $4.68 \pm 1.82$ & $2.15-8.18$ & $3.72 \pm 1.52$ & 2.01-7.73 & $3.63 \pm 1.50$ & $2.01-7.60$ \\
\hline $\begin{array}{c}\text { Ash content (\%dry } \\
\text { weight) }\end{array}$ & $19.82 \pm 6.62$ & 8.59-33.28 & $16.44 \pm 6.53$ & $8.07-30.22$ & $15.71 \pm 6.59$ & 7.97-31.47 \\
\hline $\begin{array}{c}\text { Fat content (\%wet } \\
\text { weight) }\end{array}$ & $4.86 \pm 1.53$ & 2.19-7.75 & $4.40 \pm 4.40$ & $2.16-7.60$ & $4.08 \pm 1.14$ & $2.15-6.43$ \\
\hline $\begin{array}{c}\text { Fat content (\% dry } \\
\text { weight) }\end{array}$ & $20.72 \pm 5.93$ & $8.58-32.71$ & $19.31 \pm 6.30$ & 9.62-31.25 & $17.60 \pm 5.05$ & $8.78-27.22$ \\
\hline $\begin{array}{c}\text { Protein contents } \\
\text { (\%wet weight) }\end{array}$ & $13.87 \pm 2.35$ & 11.16-20.11 & $14.68 \pm 2.59$ & $11.12-20.41$ & $15.66 \pm 3.36$ & $10.67-20.49$ \\
\hline $\begin{array}{c}\text { Protein contents } \\
\text { (\%dry weight) }\end{array}$ & $59.45 \pm 8.55$ & 45.49-79.55 & $64.25 \pm 8.27$ & $43.75-79.18$ & $66.69 \pm 10.03$ & 44.00-81.47 \\
\hline
\end{tabular}

Table 2: Regression of \% water against \% body constituents of $L$. calbasu

\begin{tabular}{|c|c|c|c|c|c|c|}
\hline & Treatment & value of "r" & $\begin{array}{c}\text { value of } \\
\text { "a" }\end{array}$ & $\begin{array}{c}\text { value of } \\
\text { "b" }\end{array}$ & $\begin{array}{c}\text { value of "S. } \\
\text { E of b" }\end{array}$ & $\begin{array}{l}\text { value of } \\
\text { " } t \text { " }\end{array}$ \\
\hline \multirow{3}{*}{$\begin{array}{c}\text { \% Water (x) } \\
\% \text { Fat wet weight (y) }\end{array}$} & T1 & 0.396* & 21.639 & -0.219 & 0.082 & -0.219 \\
\hline & T2 & $0.309^{\text {ns }}$ & 19.206 & -0.192 & 0.096 & -0.192 \\
\hline & T3 & $0.129^{n s}$ & 8.345 & -0.056 & 0.070 & -0.056 \\
\hline \multirow{3}{*}{$\begin{array}{c}\text { \% Water (x) } \\
\% \text { Fat dry weight (y) }\end{array}$} & T1 & $0.232^{\mathrm{ns}}$ & 62.210 & -0.553 & 0.377 & -0.553 \\
\hline & T2 & $0.002^{\text {ns }}$ & 19.636 & -0.004 & 0.425 & -0.004 \\
\hline & T3 & $0.275^{\text {ns }}$ & -22.653 & 0.525 & 0.298 & 0.525 \\
\hline \multirow{3}{*}{$\begin{array}{c}\% \text { Water }(x) \\
\% \text { Protein wet weight }(y)\end{array}$} & T1 & $0.513 * * *$ & 47.269 & -0.436 & 0.118 & -0.436 \\
\hline & T2 & $0.675 * * *$ & 70.896 & -0.728 & 0.129 & -0.728 \\
\hline & T3 & $0.737 * * *$ & 87.508 & -0.938 & 0.140 & -0.938 \\
\hline \multirow{3}{*}{$\begin{array}{c}\% \text { Water }(x) \\
\% \text { Protein dry weight(y) }\end{array}$} & T1 & $0.205^{\mathrm{ns}}$ & 10.992 & 0.633 & 0.490 & 0.633 \\
\hline & T2 & $0.127^{\text {ns }}$ & 98.053 & -0.438 & 0.554 & -0.438 \\
\hline & T3 & $0.296^{\mathrm{ns}}$ & 152.641 & -1.122 & 0.588 & -1.122 \\
\hline \multirow{3}{*}{$\begin{array}{c}\text { \%Water }(x) \\
\% \text { Ash wet weight }(y)\end{array}$} & T1 & $0.526 * * *$ & 31.093 & -0.345 & 0.090 & -0.345 \\
\hline & T2 & $0.126^{\mathrm{ns}}$ & 9.898 & -0.080 & 0.102 & -0.08 \\
\hline & T3 & $0.012^{\text {ns }}$ & 4.147 & -0.007 & 0.092 & -0.007 \\
\hline \multirow{3}{*}{$\begin{array}{c}\text { \% Water }(x) \\
\% \text { Ash dry weight }(y)\end{array}$} & T1 & $0.232^{\mathrm{ns}}$ & 62.210 & -0.553 & 0.377 & -0.553 \\
\hline & T2 & $0.163^{\mathrm{ns}}$ & -17.689 & 0.442 & 0.435 & 0.442 \\
\hline & T3 & $0.239^{\mathrm{ns}}$ & -29.988 & 0.596 & 0.393 & 0.596 \\
\hline
\end{tabular}


Table 3: regression results $\log$ fish weight against different body parameters in wet $(\log )$ in $L$. calbasu $(\mathrm{n}=40)$

\begin{tabular}{|c|c|c|c|c|c|c|}
\hline Relationships & Treatment & Value of "r" & $\begin{array}{c}\text { Value of } \\
\text { "a" }\end{array}$ & $\begin{array}{c}\text { Value of } \\
\text { "b" }\end{array}$ & $\begin{array}{l}\text { Value of } \\
\text { "b" (S.E) }\end{array}$ & $\begin{array}{c}\text { Value of " } t \text { " } \\
(b=1)\end{array}$ \\
\hline \multirow{3}{*}{$\begin{array}{l}\text { Log fish weight }=x \\
\text { Log water }=y\end{array}$} & T1 & $0.998 * * *$ & -0.133 & 1.014 & 0.011 & -89.8951 \\
\hline & T2 & $0.997 * * *$ & -0.082 & 0.977 & 0.012 & -82.3563 \\
\hline & T3 & $0.996 * * *$ & -0.066 & 0.963 & 0.014 & -70.4656 \\
\hline \multirow{3}{*}{$\begin{array}{c}\text { Log fish weight }=x \\
\text { Log fat }=y\end{array}$} & T1 & $0.798 * * *$ & -1.087 & 0.796 & 0.097 & -9.51328 \\
\hline & T2 & $0.764 * * *$ & -1.461 & 1.059 & 0.145 & -5.83755 \\
\hline & T3 & $0.681 * * *$ & -0.992 & 0.693 & 0.121 & -7.57146 \\
\hline \multirow{3}{*}{$\begin{array}{l}\text { Log fish weight }=x \\
\text { Log protein }=y\end{array}$} & T1 & $0.975 * * *$ & -1.048 & 1.150 & 0.042 & -22.6595 \\
\hline & T2 & $0.960 * * *$ & -1.183 & 1.254 & 0.060 & -15.4127 \\
\hline & T3 & $0.951 * * *$ & -1.384 & 1.420 & 0.075 & -11.9133 \\
\hline \multirow{3}{*}{$\begin{array}{c}\text { Log fish weight }=x \\
\text { Log ash }=y\end{array}$} & T1 & $0.643 * * *$ & -0.672 & 0.437 & 0.084 & -11.4678 \\
\hline & T2 & $0.472 * *$ & -0.653 & 0.403 & 0.122 & -7.79372 \\
\hline & T3 & $0.412 * *$ & -0.659 & 0.399 & 0.143 & -6.59401 \\
\hline
\end{tabular}

Table 4: Regression of total length against total values of different body contents in L. calbasu $(\mathrm{n}=40)$

\begin{tabular}{|c|c|c|c|c|c|c|}
\hline Relationships & Treatment & Value of "r" & $\begin{array}{c}\text { Value of } \\
\text { "a" }\end{array}$ & $\begin{array}{c}\text { Value of } \\
\text { "b" }\end{array}$ & $\begin{array}{l}\text { Value of } \\
\text { "b" (SE) }\end{array}$ & $\begin{array}{c}\text { Value of " } t \text { " } \\
(b=3)\end{array}$ \\
\hline \multirow{3}{*}{$\begin{array}{l}\text { Log fish length }=x \\
\text { Log water }=y\end{array}$} & T1 & $0.947 * * *$ & -1.689 & 2.663 & 0.146 & -17.8849 \\
\hline & T2 & $0.983 * * *$ & -1.880 & 2.890 & 0.088 & -31.2009 \\
\hline & T3 & $0.974 * * *$ & -1.806 & 2.821 & 0.107 & -25.2164 \\
\hline \multirow{3}{*}{$\begin{array}{c}\text { Log fish length }=x \\
\text { Log fat }=y\end{array}$} & T1 & $0.829 * * *$ & -2.516 & 2.289 & 0.250 & -9.711 \\
\hline & T2 & $0.732 * * *$ & -3.313 & 3.042 & 0.459 & -3.49395 \\
\hline & T3 & $0.668 * * *$ & -2.252 & 2.037 & 0.368 & -6.11517 \\
\hline \multirow{3}{*}{$\begin{array}{l}\text { Log fish length }=x \\
\text { Log protein }=y\end{array}$} & T1 & $0.929 * * *$ & -2.824 & 3.032 & 0.195 & -12.3526 \\
\hline & T2 & $0.925 * * *$ & -3.401 & 3.625 & 0.241 & -8.82313 \\
\hline & T3 & $0.930 * * *$ & -3.949 & 4.158 & 0.266 & -7.1202 \\
\hline \multirow{3}{*}{$\begin{array}{l}\text { Log fish length }=x \\
\log \text { ash }=y\end{array}$} & T1 & $0.543 * * *$ & -1.207 & 1.019 & 0.256 & -10.6998 \\
\hline & T2 & $0.436 * *$ & -1.314 & 1.117 & 0.374 & -6.90439 \\
\hline & T3 & $0.432 * *$ & -1.472 & 1.253 & 0.424 & -5.82247 \\
\hline
\end{tabular}


Table 5: Regression results of condition factor (K) against different body contents in wet fish weight of $L$. calbasu

\begin{tabular}{|c|c|c|c|c|c|c|}
\hline Relationships & Treatment & Value of "r" & $\begin{array}{c}\text { Value of } \\
\text { "a" }\end{array}$ & $\begin{array}{c}\text { Value of } \\
\text { "b" }\end{array}$ & $\begin{array}{l}\text { Value of } \\
\text { "b" (SE) }\end{array}$ & $\begin{array}{l}\text { Value of } \\
\text { "t } t(b=0)\end{array}$ \\
\hline \multirow{3}{*}{$\begin{array}{c}\text { Condition factor }=\mathbf{x} \\
\% \text { Water }=\mathbf{y}\end{array}$} & T1 & $0.030^{\text {ns }}$ & 76.190 & 0.335 & 1.799 & 0.335 \\
\hline & T2 & 0.393* & 89.538 & -9.474 & 3.601 & -9.474 \\
\hline & T3 & $\mathrm{0.033}^{\mathrm{ns}}$ & 75.431 & 0.922 & 4.467 & 0.922 \\
\hline \multirow{3}{*}{$\begin{array}{c}\text { Condition factor }=\mathbf{x} \\
\% \text { Fat }=y\end{array}$} & T1 & $0.313 *$ & 7.169 & -1.922 & 0.945 & -1.922 \\
\hline & T2 & $0.124^{\text {ns }}$ & 1.981 & 1.860 & 2.410 & 1.86 \\
\hline & T3 & $0.031^{\text {ns }}$ & 4.553 & -0.365 & 1.934 & -0.365 \\
\hline \multirow{3}{*}{$\begin{array}{c}\text { Condition factor }=\mathbf{x} \\
\% \text { Protein }=\mathbf{y}\end{array}$} & T1 & $0.078^{\text {ns }}$ & 14.759 & -0.740 & 1.525 & -0.74 \\
\hline & T2 & $0.277^{\mathrm{ns}}$ & 5.284 & 7.209 & 4.059 & 7.209 \\
\hline & T3 & $0.060^{\text {ns }}$ & 12.912 & 2.094 & 5.676 & 2.094 \\
\hline \multirow{3}{*}{$\begin{array}{c}\text { Condition factor }=\mathbf{x} \\
\% \text { Ash }=y\end{array}$} & T1 & $0.320 *$ & 1.881 & 2.327 & 1.118 & 2.327 \\
\hline & T2 & $0.026^{n s}$ & 3.197 & 0.405 & 2.482 & 0.405 \\
\hline & T3 & $0.170^{\mathrm{ns}}$ & 7.104 & -2.652 & 2.499 & -2.652 \\
\hline
\end{tabular}

\section{DISCUSSION}

Results of the present study represented the lowest water contents and the highest protein contents in T3, when fish were fed a diet containing $25 \%$ crude protein in diet. The results are similar to those reported by Ishtiaq and Naeem [8] who had also studied the effect of dietary protein levels on body composition of another carp Catla catla, and found significantly higher protein percentage and lower water percentage in the fish samples, fed upon a diet having 25\% CP. Kim et al. [11] fed parrot fish (Oplegnathus fasciatus) with different protein levels, and also reported that protein and lipid increases with dietary protein. Satpathy et al. [12] had evaluated the effects of dietary protein on body composition in, Labeo rohita, fingerlings and also reported that body protein and lipid contents increased significantly $(P<0.05)$ with dietary protein level as well as under the influence of the interactive effect of dietary protein levels.

In the present study, whole body protein content of L. calbasu increased with the increasing dietary protein levels which agree with the results found by Kim et al. [11] and Ishtiaq and Naeem [8]. Proximate composition of L. calbasu in terms of fat was not affected by dietary protein levels, which are in accordance with Kim et al. [11]. However, generally body lipid content increases with the increase in dietary protein levels as reported by Bai et al. [13] for yellow puffer. Ash contents in the whole body of the fish decreases with an increase in dietary protein level, in the 
present study. On the contrary, Kim et al.

[11] for juvenile parrot fish and Okorie et al. [14] for juvenile Japanese eel had reported that ash contents of fish fed with the experimental diets was not significantly affected by dietary protein levels.

Percentage of the water content in fish body generally influences the percentage of other body contents as reported by various authors [8, 15]. However, in the present study, percent water remained constant in many relations with different body constituents, but found significant with protein contents of the L. calbasu in all three treatments. Naeem et al. [16] also reported same results in wild Notopterus notopterus.

Body size of $L$. calbasu showed definite effect on the various body constituents in the fish, collected from different treatments which were fed various dietary protein levels (Table 3 and 4). When the allometric approach was applied on log-transformed regression relationships between total body constituents and body weight or length by comparing with $b=1$ or $b=3$ (an isometric slope), following Weatherley and Gill [17] and Salam and Davies [5], results showed negative allometry in ash while positive allometry in protein content with the fish size. It indicated that protein contents in the fish body increase at an accelerating rate, defying the cube law (positive allometry, b> 3), which is in general agreement with the studies reported by Salam and Davies [5] and Khalid and Naeem [18]. While, Salam and Davies [5] found that ash was isometric with fish body weight and positive allometric with total length of the fish. The variation in the results might be due to difference in fish body size.

Most of the regression relationships between condition factor and various body constituents showed non significant correlation, the results are in accordance with those reported by Naeem and Ishtiaq [19] for wild Mystus bleekeri.

It is concluded that various levels of dietary protein have definite effect on the body composition. Moreover, size of fish also influences on the percentage of various body constituents of Labeo calbasu. Hence different body contents can be estimated from fish length or weight.

Conflict of Interest: No conflict of interest associated with this work.

\section{REFERENCES}

[1]Talwar PK, Jhingran AG. Inland Fishes of India and Adjacent countries, Bombay: Oxford and IBH Publishing Co. Vol. I and II; 1991.

[2] Shehawy SME, Gab-Alla AA, Mutwally HMA, Proximate and elemental composition of important fish species in Makkah central fish market, Saudi Arabia. Food Nut Sci 2016; 07: 429439. 
[3]Dempson JB, Schwarz CJ, Shears M, Furey G, Comparative proximate body composition of Atlantic salmon with emphasis on parr from fluvial and lacustrine habitats. J. Fish Biol 2004; 64(5):1257-1271.

[4]Mohamed HE, Al-Maqbaly R, Mansour HM, Proximate composition, amino acid and mineral contents of five commercial Nile fishes in Sudan. African J Food Sci 2010; 4(10): 640-654.

[5]Salam A, Davies PMC. Body composition of northern pike (Esox lucius L.) in relation to body size and condition factor. J Fish Res 1994; 19: 193-204.

[6]Naeem M, Salam A, Zuberi A. Proximate composition of freshwater Rainbow trout (Oncorhynchus mykiss) in relation to body size and condition factor from Pakistan. Pakistan J Agri Sci 2016; 53(2): 497-502.

[7]Ashraf M, Zafar A, Naeem $M$. Comparative Studies on the Seasonal Variations in the Nutritional Values of Three Carnivorous Fish Species. Inter J Agri Biol 2011; 13(5): 701-706.

[8]Ishtiaq, A, Naeem, M, Effect of Dietary Protein Levels on Body Composition of Catla catla from Pakistan. Sindh Univ Res J (Sci. Ser.) 2019; 51 (2): 309-318. [9]Alam M., Amin SMN, Haroon AKY. Population dynamics of Labeo calbasu
(Hamilton) in the Sylhet basin. Ind J Fisher 2000; 47(1): 1-6.

[10] Bligh EG, Dyer WJ. A rapid method of total lipid extraction and purification. Canadian J Biocham Physiol 1959; 37: 911-917.

[11] Kim K, Moniruzzaman M, Kim K, Han SH, Yun $\mathrm{H}$, Lee S, Bai SC. Effects of dietary protein levels on growth performance and body composition of juvenile parrot fish, Oplegnathus fasciatus. Effects of dietary protein levels on growth performance and body composition of juvenile parrot fish, Oplegnathus fasciatus. Inter Aquatic Res 2016; 8(3): 239-245.

[12] Satpathy BB, Mukherjee D, Ray AK. Effects of dietary protein and lipid levels on growth, feed conversion and body composition in rohu, Labeo rohita (Hamilton), fingerlings. Aquaculture Nut 2003; 9(1): 17-24.

[13]Bai SC, Wang XJ, Cho ES. Optimum dietary protein level for maximum growth of juvenile yellow puffer. Fish Sci 1999; 65:380-383.

[14] Okorie EO, Kim YC, Lee S, Bae JY, Yoo JH, Han K, Park GJ, Choi SM and Bai SC. Reevaluation of the dietary protein requirements and optimum dietary protein to energy ratios in 
Japanese eel, Anguilla japonica. J World Aqua Soc 2007; 38: 418-426.

[15] Naeem M; Salam A. Proximate composition of fresh water bighead carp, Aristichthys nobilis, in relation to body size and condition factor from Islamabad, Pakistan. Afr J Biotechnol 2010; 9: 8687-8692.

[16] Naeem M, Rasul A, Salam A, Iqbal S, Ishtiaq A, Athar M. Proximate Analysis Of Female Population Of Wild Featherback Fish (Notopterus notopterus) In Relation To Body Size And Condition Factor. Afr J Biotechnol 2011; 10(19): 3867-3871.
[17] Weatherley AH, Gill HS. The biology of fish growth. Academic Press, London; 1987.

[18] Khalid M, Naeem M. Proximate Analysis of Grass Carp (Ctenopharyngodon idella) from Southern Punjab, Pakistan. Sarhad J Agri 2018; 34(3): 633.

[19] Naeem M, Ishtiaq A. Proximate composition of Mystus bleekeri in relation to body size and condition factor from Nala Daik, Sialkot, Pakistan. Afr J Biotechnol 2011;10(52): $\quad 10765-\quad 10773$. https://doi.org/10.5897/AJB10.2339. 